\title{
"Assessment of public welfare in Ukraine in the context of the COVID-19 pandemic and economy digitalization"
}

\author{
Serhii Kozlovskyi iD https://orcid.org/0000-0003-0707-4996 \\ R http://www.researcherid.com/rid/P-3856-2017 \\ laroslav Petrunenko iD https://orcid.org/0000-0002-1186-730X \\ R https://publons.com/researcher/B-8162-2019 \\ AUTHORS \\ Viktoriia Baidala (D https://orcid.org/0000-0002-1532-2913 \\ R https://publons.com/researcher/H-7162-2018 \\ Viktoriia Myronchuk iD https://orcid.org/0000-0002-1720-4558 \\ R http://www.researcherid.com/rid/H-4155-2017 \\ Tetiana Kulinich iD https://orcid.org/0000-0003-0110-7080 \\ R https://publons.com/researcher/R-6627-2017
}

Serhii Kozlovskyi, laroslav Petrunenko, Viktoriia Baidala, Viktoriia Myronchuk

ARTICLE INFO and Tetiana Kulinich (2021). Assessment of public welfare in Ukraine in the context of the COVID-19 pandemic and economy digitalization. Problems and Perspectives in Management, 19(1), 416-431. doi:10.21511/ppm.19(1).2021.35

DOI http://dx.doi.org/10.21511/ppm.19(1).2021.35

RELEASED ON Monday, 29 March 2021

RECEIVED ON

Wednesday, 20 January 2021

ACCEPTED ON

Thursday, 18 March 2021

\section{(cc) EY}

LICENSE

This work is licensed under a Creative Commons Attribution 4.0 International License

JOURNAL

"Problems and Perspectives in Management"

ISSN PRINT 1727-7051

ISSN ONLINE $1810-5467$

PUBLISHER

LLC "Consulting Publishing Company "Business Perspectives"

FOUNDER

LLC "Consulting Publishing Company "Business Perspectives"

NUMBER OF REFERENCES

48
NUMBER OF FIGURES

13
NUMBER OF TABLES

2

(C) The author(s) 2021. This publication is an open access article. 


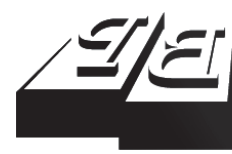

\section{BUSINESS PERSPECTIVES}

LLC "CPC "Business Perspectives" Hryhorii Skovoroda lane, 10, Sumy, 40022, Ukraine www.businessperspectives.org
Received on: $20^{\text {th }}$ of January, 2021 Accepted on: $18^{\text {th }}$ of March, 2021 Published on: $29^{\text {th }}$ of March, 2021

(c) Serhii Kozlovskyi, Iaroslav Petrunenko, Viktoriia Baidala, Viktoriia Myronchuk, Tetiana Kulinich, 2021

Serhii Kozlovskyi, Doctor of Economics, Professor, Faculty of Economics, Department of Entrepreneurship, Corporate and Spatial Economics, Vasyl' Stus Donetsk National University, Ukraine. (Corresponding author)

Iaroslav Petrunenko, Ph.D., Professor Department of Economic Law and Procedure, National University "Odessa Law Academy", Ukraine.

Viktoriia Baidala, Doctor of Economics Professor, Department of Economic Theory, National University of Life and Environmental Sciences of Ukraine, Ukraine.

Viktoriia Myronchuk, Ph.D., Associate Professor, Department of Finance, Banking and Insurance, Vinnytsia Education and Research Institute of Economics' West Ukrainian National University, Ukraine.

Tetiana Kulinich, Ph.D., Associate Professor, Department of Organizational Management, Lviv Polytechnic National University, Ukraine.

This is an Open Access article, distributed under the terms of the Creative Commons Attribution 4.0 International license, which permits unrestricted re-use, distribution, and reproduction in any medium, provided the original work is properly cited.

Conflict of interest statement: Author(s) reported no conflict of interest

Serhii Kozlovskyi (Ukraine), Iaroslav Petrunenko (Ukraine), Viktoriia Baidala (Ukraine), Viktoriia Myronchuk (Ukraine), Tetiana Kulinich (Ukraine)

\title{
ASSESSMENT OF PUBLIC WELFARE IN UKRAINE IN THE CONTEXT OF THE COVID-19 PANDEMIC AND ECONOMY DIGITALIZATION
}

\begin{abstract}
With the emergence of the global COVID-19 pandemic in 2019, a process of transformation of the modern economic system took place, which requires new approaches to assessing economic processes. One of such processes is the assessment of public welfare. The purpose of this study is to develop an approach to assessing the level of public welfare of the population of Ukraine in the context of the COVID-19 pandemic and economy digitalization. To solve this problem, the methods of artificial intelligence, in particular the method of fuzzy sets theory, which allows using the incomplete information and making high-quality forecast calculations, are used. The factors influencing the level of public welfare during the COVID-19 pandemic have been identified. These are the following factors: gross domestic product, poverty rate, welfare index, human development index, subsistence level, and indicators that characterize the COVID-19 pandemic (i.e. the total number of COVID-19 cases, the total number of deaths from COVID-19, and the total number of vaccinations from COVID-19 in Ukraine). Using fuzzy sets theory, an economic-mathematical model for assessing the level of public welfare in the context of the COVID-19 pandemic in Ukraine was built. Two-dimensional dependences of the level of public welfare of Ukraine in the context of the COVID-19 pandemic on indicators such as gross domestic product, subsistence level, and the total number of cases of COVID-19 in Ukraine were obtained. The results of the study established that the level of public welfare in the context of the COVID-19 pandemic on the $0-100$ scale is predicted to be as follows points: $2021-17,2022-$ 23, $2023-27,2024-19,2025-35$ and will not meet international standards.
\end{abstract}

Keywords

JEL Classification

\section{INTRODUCTION}

In the context of the digital economic development of today's world, a force-majeure factor has arisen, halting the transition to socio-economic development based on knowledge, education, and innovation. This factor is the COVID-19 pandemic, which has significantly changed the vectors of global economic development and has negatively affected the level of social welfare of the population of all countries of our planet.

Classical theoretical concepts of progress, such as the broad democratization of socioeconomic life, the expansion of non-commodity production and non-commodity relations (in the fields of social services, science, and education), limitation of the scope of traditional mecha- 
nisms of the market economy, the creation of a wide network of public organizations, and the search for innovative developments have become secondary to the global COVID-19 pandemic.

Until 2019, a set of features for assessing the level of public welfare could be identified based on the implementation of a new quality of socio-economic relations. First, there was a sharp dynamic in the needs of the population and technology, which predetermined a qualitative increase in the level of indeterminism of socio-economic processes. Secondly, the most crucial quality of a person or an institution was the ability to adapt quickly to the changing circumstances and priorities of society. Thirdly, the production became individualized, meaning that the focus shifted to the needs of a particular consumer. Next, human capital investment became a key priority of governmental policies. Finally, the institutional crisis of human capital industries, caused by fundamental shifts in society, formed a general level of public welfare of the population of the country (Kozlovskyi et al., 2020).

However, with the advent of the COVID-19 pandemic, the situation in assessing the level of public welfare began to change. The indicators of the level of medicine, digital technology and unforeseen force majeure factors began to come to the fore. It became obvious that a new approach to understanding social progress in the new socio-economic conditions was needed. This approach prioritizes the individual and the expansion of life choices availability (Banerjee et al., 2016). Moreover, it provides several solutions to fight poverty that are still highly relevant. Lastly, it offers a new understanding of processes to increase safety, improve healthcare, and develop modern healthcare systems.

In accordance with the criteria by which one can judge social welfare, concepts of welfare have been developed that draw attention to various structural elements under this category and try to measure them. Two diametrically opposed conceptual approaches in public welfare theory have profoundly influenced empirical research on public welfare: the Nordic or the Swedish model (resource approach) and the American model (behavioral approach).

According to the former model (the Nordic model), welfare is defined as "individual management of available resources, using which a person can control and consciously manage their living conditions" (Erikson, 1993). One of the key issues an individual faces in all stages of societal development is a shortage of resources needed for a decent level of life. This understanding is based on the notion that a person is active, creative, and independently determines his/her goals and aims to achieve the desired result. In this case, individual resources, in addition to income and savings, also encompass the level of education and health care i.e., human capital, a set of accumulated and annually multiplied social qualities, which a person then develops in labor.

The second approach (the American model) mainly focuses on the importance of subjective perception and evaluation. The welfare of an individual is the main indicator to ultimately measure and evaluate societal development because this approach dictates that welfare and the quality of life are perceived subjectively.

Reasonably, though a subjective factor does undeniably influence public welfare, the first approach, based on the processing of objective data, is believed to have a practical value to systematically analyze societal wellbeing. Taking these variables into account and assessing them is the main aspect of the development of a national economy and the welfare of its citizens. This issue can be solved using digital economy and artificial intelligence methods that allows analyzing both qualitative and quantitative factors. Using the simulation of human intelligence, one can obtain highly accurate forecasts of needed measures. The most suitable solution is fuzzy sets theory, which has been successfully used to address similar economic problems (Kozlovskyi et al., 2018). 


\section{THEORETICAL BASIS}

\subsection{Public welfare theories}

Many researchers equate quality of life and public welfare, which is described as the extent to which one is endowed with material and non-material goods and services, as well as adequate conditions necessary for one's comfortable and safe existence. A high societal standard is achieved through continuous economic growth, whereas a fair distribution of benefits and income ensures a high standard on an individual level.

Labor is the main source of income for the majority of the population. This approach, which identifies productivity as one of the main labor variables, is described in H. Bergson's Creative Revolution (Bergson, 1911) and J. Schumpeter's The Theory of Economic Development (Schumpeter, 2008). For example, the material basis for continuous improvement of the quality of life is achieved through the systematic development of social production and steady growth of national income. The national income is the means of increasing social welfare: its growth allows increasing the volume of public consumption. The growth of the national income directly correlates with an increase in all essential factors that characterize the material welfare of the population, i.e., higher income, which in turns increases the number of purchased goods and services plus price index, taxes, and other mandatory payments (Ilyash et al., 2020). Therefore, economic growth and employment and salary dynamics were the primary parameters of the models of public welfare until 2019. The COVID-19 pandemic profoundly disrupted the understanding of typical models of public welfare assessment, thus causing a shift in the scientific approach of assessing public welfare. New factors, such as the level of development of health care, the availability of vaccines, etc., emerged, building the foundation of these concepts.

Welfare economics is the system of views in economic science on the economic optimum and the ways to achieve it through the instruments of state economic policy (DiNitto, 2003). The most famous work in the field of the economic theory of welfare is the treatise of V. Pareto (1935), which is called the "New Economic Theory of Welfare".
This concept is deemed novel because it provides an original view on the interpersonal commensurability of utility (Tsymbaliuk et al., 2019).

The work of the representative of the Cambridge School Pigou (1932), who proposed using the category of "national dividend", can be attributed to the classical approach to assessing well-being. This approach shares the understanding of social welfare and individual welfare according to the criterion of this welfare magnitude.

In modern economic theory, the works of V. Pareto and A. Pigou are fundamental, which is opposed only by theorem of Arrow (1951) "On the impossibility of collective choice" (Arrow, 1951) that explains the human perception of welfare. Although this approach has been criticized from the standpoint of the impossibility of the same understanding of personal and public welfare (List \& Goodin, 2001). The impossibility of the same understanding of the categories of social and personal welfare is described in the famous work of Smith (1776) in "An Inquiry into the Nature and Causes of the Wealth of Nations".

Although A. Campbell argues that the traditional economic indicators of the population's well-being have attractive characteristics but also emphasizes their inadequacy. Campbell (1976) states that rapid economic development has generally not been associated with comparable increases in wealth. Subsequently, the authors of the Human Development Report published by the United Nations Development Program (UNDP) write, "Studying the rise and fall of national incomes, economists had often lost sight of the real goal of the development of society, which is the well-being of people. Economic development is simply an important means to achieving this goal". The UNDP adds that "...well-being relies on not only on economic growth and national income levels, but it also depends on how these resources are used: whether to develop weapons and build palaces or produce food and provide clean water" (Human Development Report, 2020).

Contemporary work in the field of public welfare theory is at the intersection of economics and other sciences. Methodological concepts and methods of philosophy are at the heart of solving problems of welfare theory. 


\subsection{Artificial intelligence and digital methods in assessing public welfare}

In sum, it can be concluded that the proposed problem, i.e., the assessment of public welfare in the context of the COVID-19 pandemic has not yet been properly researched to address several controversial and unsolved issues. An interdisciplinary approach is one possible solution. This method was supported by the Club of Rome in 2018 (Weizsacker \& Wijkman, 2018). Artificial intelligence methods will be used to solve the problem posed, in accordance with the philosophy of this research.

Artificial intelligence methods have a number of differences from classical and traditional methods. Classical and traditional methods cannot give a good result in the face of uncertainty in an extremely dynamic developing economic environment. These methods are based on binary logic, which does not make it possible to qualitatively consider evaluative phenomena in the process of describing an economic object. The solution to this problem is possible thanks to the use of modern digital methods, such as the methods of fuzzy set theory, which have justified themselves for solving other similar economic problems (Kozlovskyi et al., 2018; Nikolenko et al., 2018; Matviychuk et al., 2019; Derbentsev et al., 2020; Oliinyk \& Kozmenko, 2019). The basic principles of the theory of fuzzy sets that can be used to assess public welfare were proposed by Rotshtein (1999), Panoshichen and Kozachko (2010), and Rotshtein and Shtovba (2009).

\subsection{Factors in assessing public welfare}

Over the last three years, the government of Ukraine has introduced 75 legislative documents on reforms in various sectors of the economy and government (Law of Ukraine "On State Social Standards and State Social Guarantees," 2018). According to Byrdyn (2008), improving the quality of life and the public welfare of the population is achieved through socio-economic development:

- increasing income;

- improving the health of the population;

- raising the level of education of the population;

- creating favorable conditions for the growth of people's self-esteem as a result of the formation of social, political, economic, and institutional systems focused on respect for human dignity;

- increasing the freedom of people, in particular their economic freedom.

A renowned scientist Bell (1976) coined 12 main criteria (indicators) that can be used to simultaneously measure "the quality of life" of different societies. These include but are not limited to: healthcare, personal development, and improvement in education, work and quality of employment, organization of leisure, distribution of goods and services, personal safety, opportunity to participate in public life, physical environment, justice (Bell, 1976).

Source: The World Bank (2020).

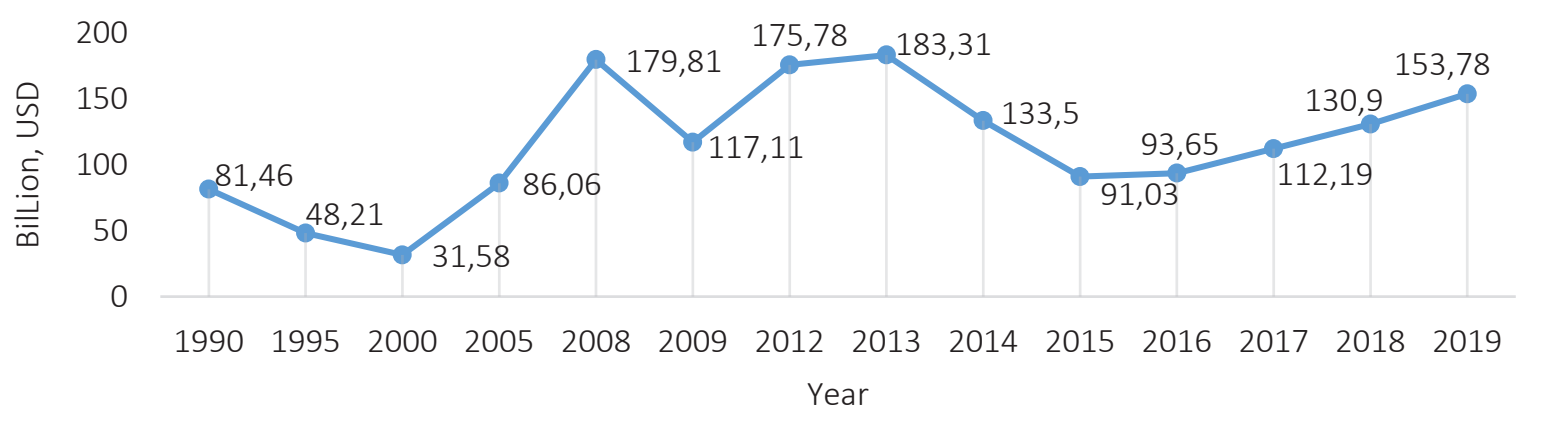

Figure 1. Ukraine's GDP in current prices, 2020 


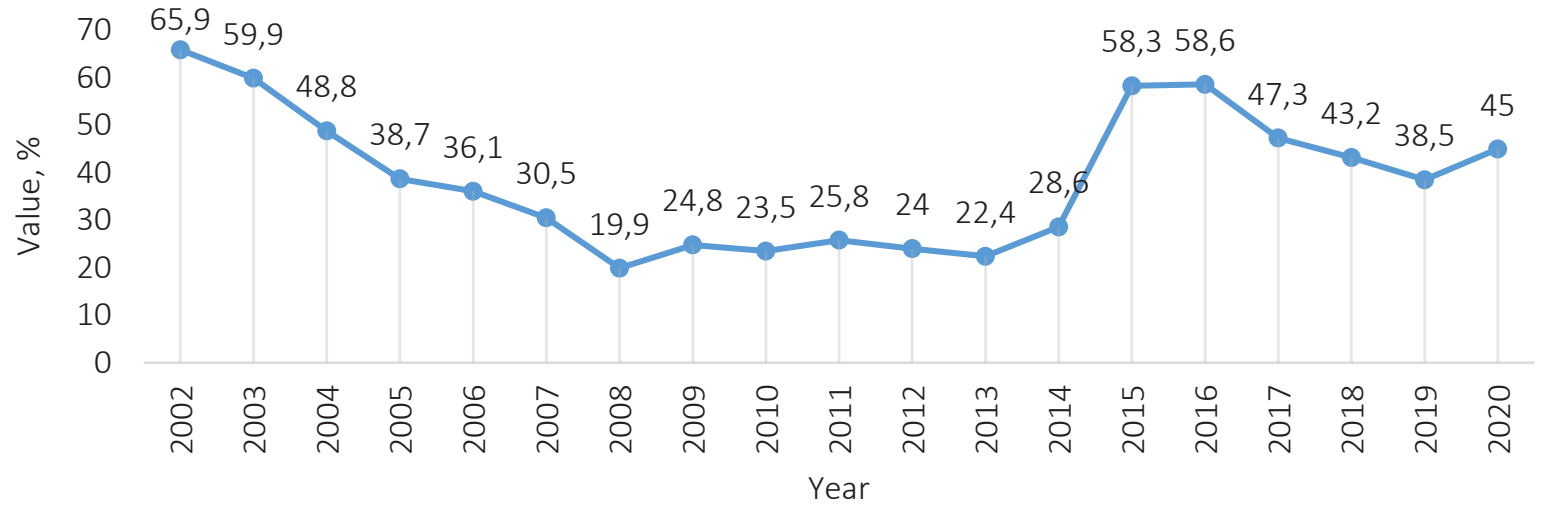

Figure 2. Poverty index of Ukraine, 2020

The main indicator of welfare in the country is the size of gross domestic product (GDP) and the human development index (HDI). The latter is calculated using GDP per capita (Koziuk et al., 2019), average life expectancy, and the level of education. The graph of changes in the level of Ukraine's GDP at current prices is shown in Figure 1.

Recently, however, politicians and scholars have begun to question the use of the GDP index to assess the public welfare. Poverty is increasingly used to assess public welfare. Poverty is the limit beyond which a person cannot be provided with the benefits necessary for life (Libanova, 2020).

According to the Human Development Report (2020), the Poverty Index in Ukraine amounts to 0.001 . Moreover, this figure has decreased over the years. Other sources, such as the United Nations (2021), indicate that more than $60 \%$ of the Ukrainian population is poor. Additionally, the International
Monetary Fund (2021) deems Ukraine to be the poorest country in Europe both in terms of GDP per capita and in the lowest wage rating $(20 \%$ of the employed population is considered to be poor). According to the Ptoukha Institute for Demography and Social Studies of the National Academy of Sciences of Ukraine, $45 \%$ of the population of Ukraine have been categorized as "poor" in 2020 (Figure 2). (Ptoukha Institute for Demography and Social Studies of the National Academy of Sciences of Ukraine, 2020). Using surveys of household living conditions, which included macroeconomic forecasts, current statistics, opinion polls, and expert estimates, the study found that the level of poverty (defined as "expenditures above the living wage level") is expected to return to the 2017 level in 2021. In 2019, the poverty rate (expenditures above the living wage level) was $38.5 \%$, which is 4.7 points or $11 \%$ lower than that of the previous year (Ptoukha Institute for Demography and Social Studies of the National Academy of Sciences of Ukraine, 2020).

Source: The Legatum prosperity index, 2020

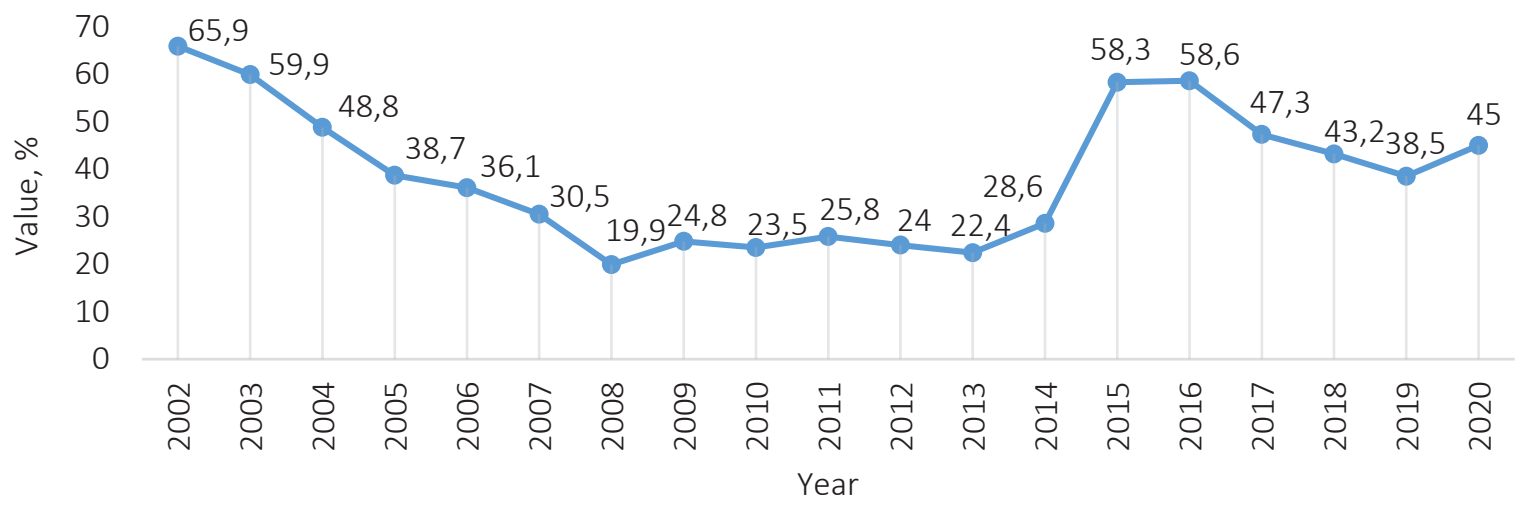

Figure 3. Legatum Prosperity Index of Ukraine, 2020 
Source: The Legatum prosperity index (2020).

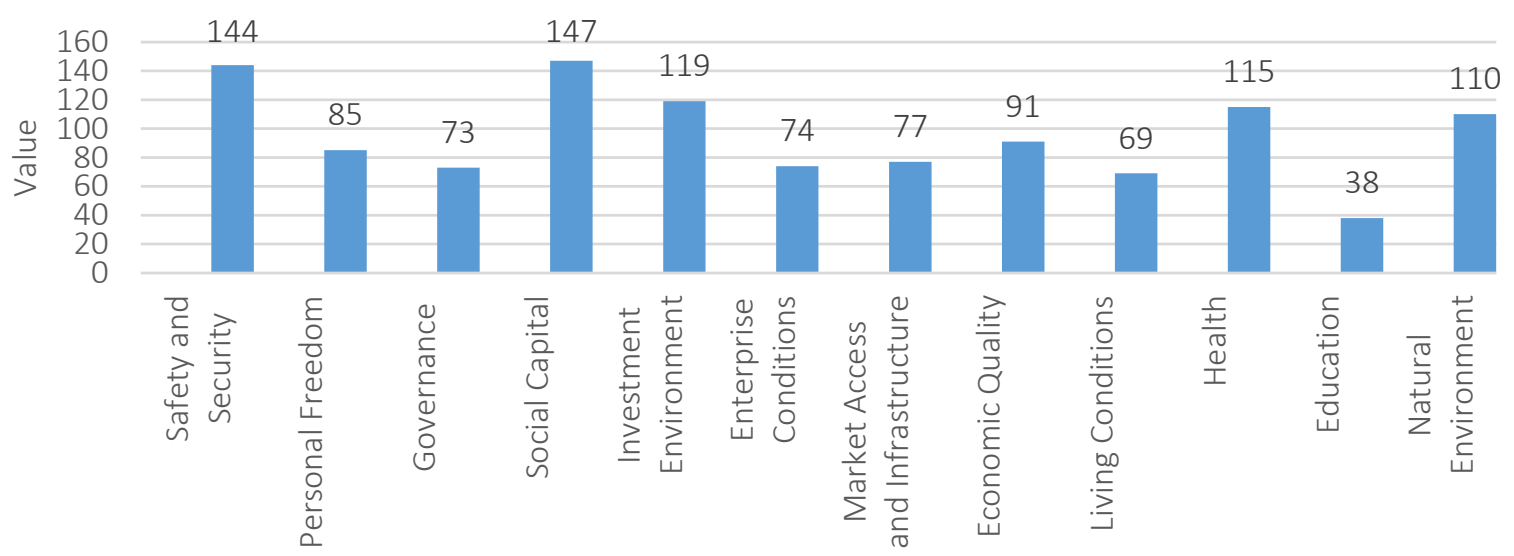

Component of the index LPI

Figure 4. Components of the integral index Legatum Prosperity Index of Ukraine, 2020

The Legatum Institute (2020) placed Ukraine 92 nd out of 167 countries in the global welfare ranking (The Legatum prosperity index, 2020). Of all European countries, Ukraine ranked last on the list. The dynamics of change of the Legatum Prosperity Index (LPI) in Ukraine over the last 10 years is shown in Figure 3.

Figure 3 shows that Ukraine ranks last in Europe on this indicator, which takes into account components such as: Safety and Security, Personal Freedom, Governance, Social Capital, Investment Environment, Enterprise Conditions, Market Access and Infrastructure, Economic Quality, Living Conditions, Health, Education, and Natural Environment (see Figure 4).

In 2019, Ukraine ranks 74th in the world in the human development index (HDI $=0.779)$. The HDI in Ukraine consists of the following indicators in 2019: Life expectancy at birth, 72.1 years; Expected years of schooling, 15.1 years; Mean years of schooling, 11.4 years; Gross national income (GNI) per capita (PPP \$), \$13,216.
The graph of the HDI change in Ukraine is shown in Figure 5.

Of particular importance in assessing public welfare is the indicator of living wage. Importantly, this indicator is determined normatively by calculating the cost of the consumer basket per person per month. The indicator is differentiated using the age criterion or the social and demographic group of the person: children under 6 years of age; children aged 6 to 18; non-disabled persons; persons who have lost their ability to work (Law of Ukraine "On State Social Standards and State Social Guarantees," 2017). The imperfection of this technique is evidenced by modern scientific works of such scientists as (Potapov, 2011).

The living wage is an important characteristic of the level of social welfare. It is a cost estimate of the consumer basket, which includes the minimum selection of food, non-food products and services necessary to maintain human health and ensure human livelihood (Babenko et al., 2019; Daqar et al., 2021). Figure 6 illustrates that the living wage

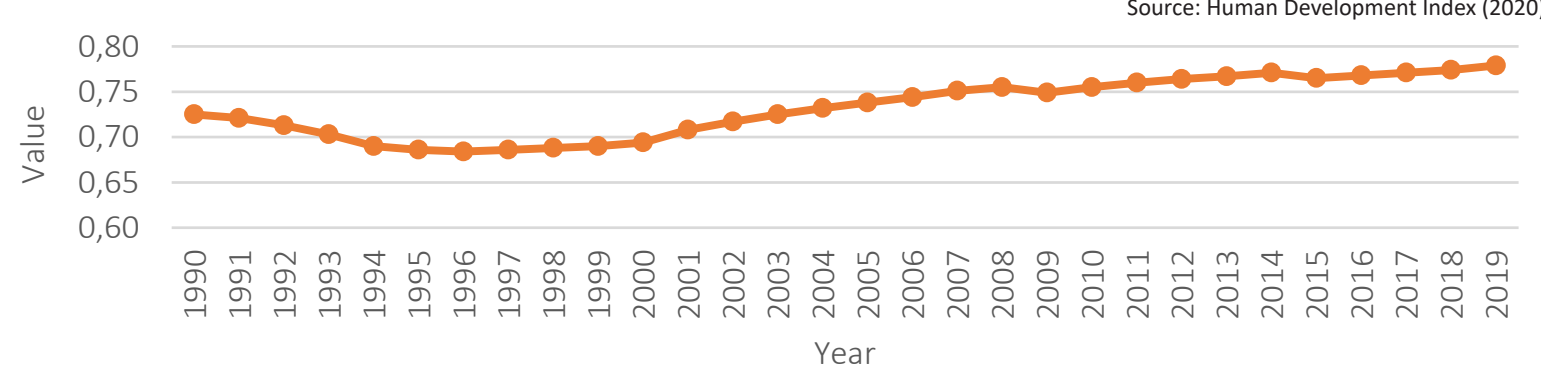

Figure 5. Human Development Index of Ukraine, 2020 


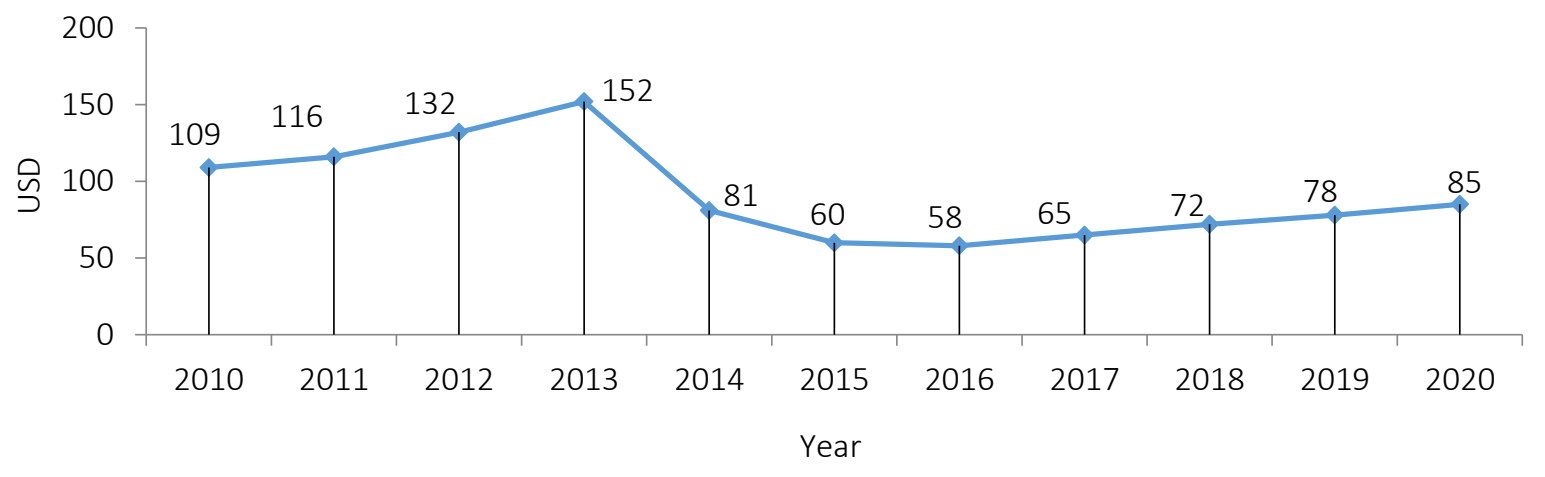

Figure 6. Living wage in Ukraine, 2020

in Ukraine in 2020 accounts for approximately 2.7 US dollars per person per day. This minimal value places Ukraine among the poorest countries in the world (countries with an indicator of less than $\$ 5$ per day are considered poor).

\section{AIMS}

The purpose of this study is to develop an approach to assessing the level of public welfare of the population of Ukraine in the context of the COVID-19 pandemic and economy digitalization.

\section{RESULTS}

The research is based on the digital economy methods, in particular fuzzy sets theory. Methodology based on fuzzy sets theory involves a step-by-step solution of the following tasks:
- identification of factors that affect the level of public welfare in Ukraine in the context of the COVID-19 pandemic;

- determination of links between influencing factors;

- determination of linguistic assessments of these factors;

- formation of a fuzzy knowledge base;

- the formation of fuzzy logical equations; and

- execution of the procedure for optimizing the parameters of this economic and mathematical model.

The following indicators of public welfare will be considered for assessing the impact of the COVID-19 pandemic (Kozlovskyi et al., 2021):

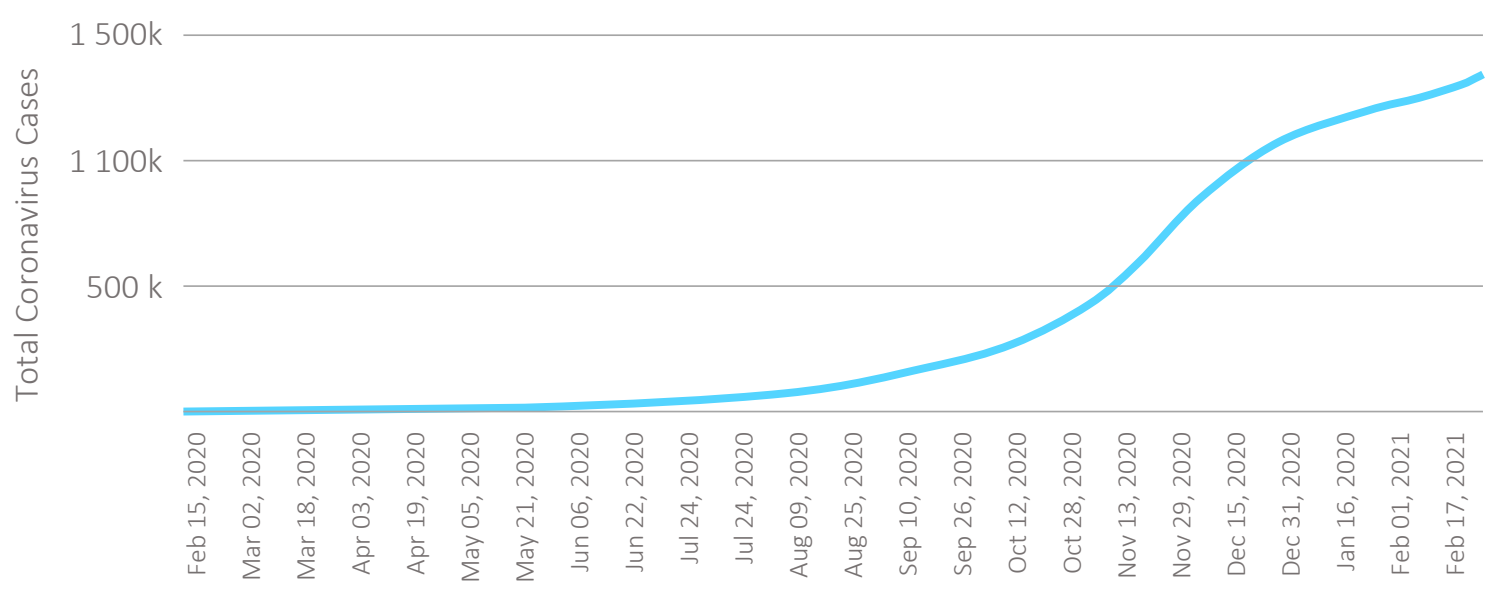

Figure 7. Coronavirus cases in Ukraine, 2021 
Source: Worldometer (2021).

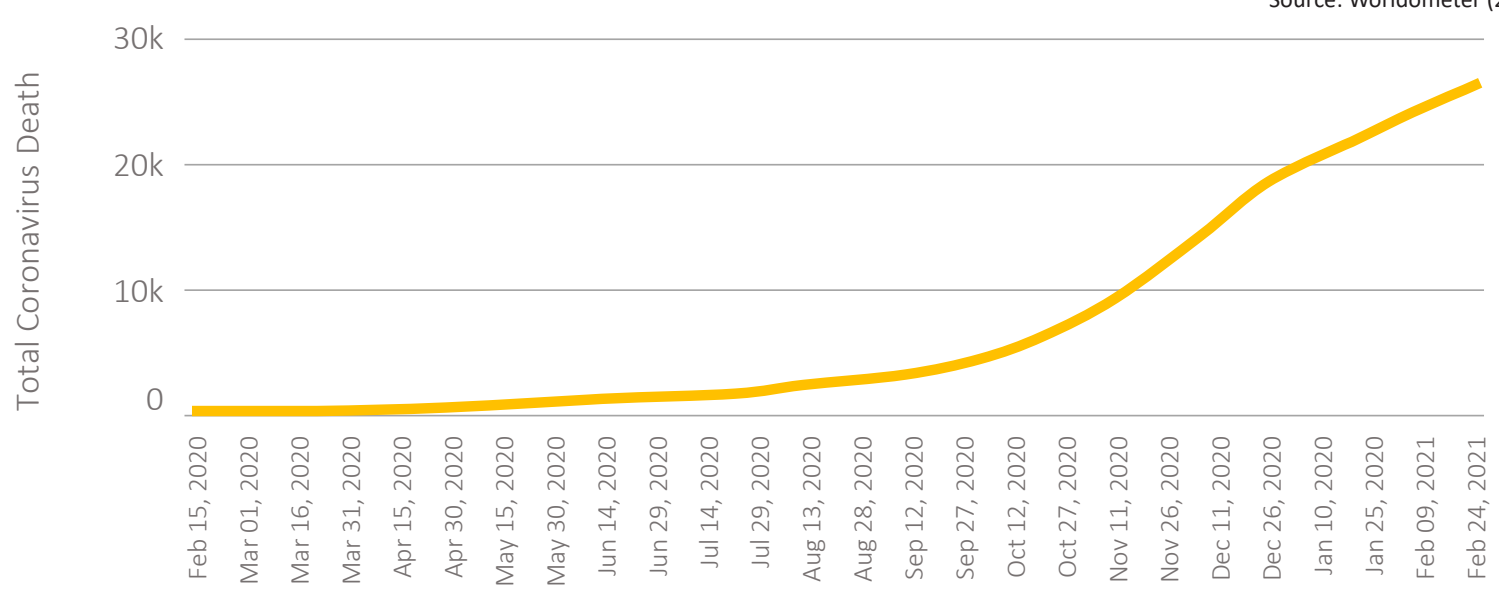

Figure 8. Total coronavirus deaths in Ukraine, 2021

the total number of COVID-19 cases in Ukraine; the total number of deaths caused by COVID-19 in Ukraine; and the total number of vaccinations against COVID-19 in Ukraine.

The trend of the number of COVID-19 cases and the number of deaths caused by COVID-19 in Ukraine as of January 2021 are presented in Figure 7 and Figure 8, respectively. The graphs shows that the growth trend for COVID-19 in Ukraine is catastrophic.

The number of COVID-19 vaccinations is an important indicator for assessing the level of public welfare in Ukraine. However, as of January 20, 2021, the vaccination campaign against COVID-19 has not yet begun in Ukraine. Nonetheless, the indica- tor itself must be taken into account when modeling and forecasting the level of public welfare.

To determine and scale the level of public welfare in the context of the COVID-19 pandemic, it is proposed to use a complex indicator, since, in its essence, the index characterizes the total change in certain values. For the sake of concision, it will be identified as the "Index of Public Welfare in Ukraine in the COVID-19 context" (hereinafter referred to as IPWU).

The value of the indicator (IPWU) will be determined using the methods of the digital economy (Petrova et al., 2020), i.e., the economic and mathematical apparatus: the theory of fuzzy sets (Kozlovskyi et al., 2020).

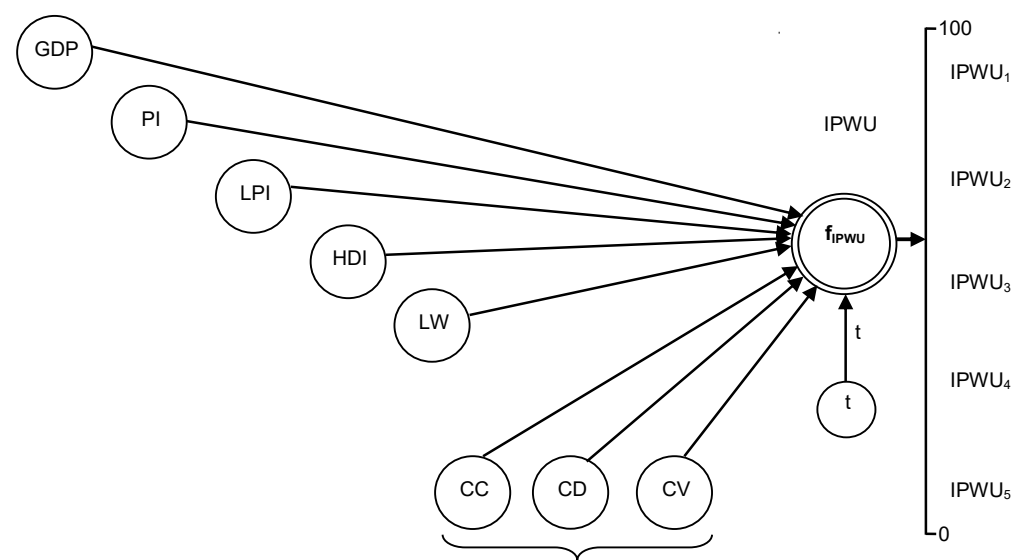

Covid-19 factors

Figure 9. Structural model for assessing public welfare in Ukraine in the context of the COVID-19 pandemic 
Figure 9 shows the input factors of the model: gross domestic product (GDP); poverty index (PI); legatum prosperity index (LPI); human development index (HDI); living wage (LW); the total number of COVID-19 cases in Ukraine (CC); the total number of deaths from COVID-19 in Ukraine (CD); the total number of COVID-19 vaccinations in Ukraine $(\mathrm{CV})$.

In its essence, Figure 9 is a structural model of assessing public welfare in Ukraine in the context of the COVID-19 pandemic.

The construction of membership functions for terms of input factors and output values will be carried out according to the methodology, which has shown high efficiency in solv- ing technical (Rotshtein \& Shtovba, 2009) and economic problems. This technique proposes to use the functions of independence based on the use of indicators: $b$ - function maximum coordinate; $c$ - stretching concentration factor (see Table 1).

Table 1 summarizes all the factors influencing the level of public welfare in Ukraine in the COVID-19 pandemic, as well as indicators of linguistic assessment of all indicators of the digital economic model.

The input indicator of IPWU, i.e., the level of public welfare in Ukraine in the context of the COVID-19 pandemic, can be determined by the following formula (1):

Table 1. Generalization of values of indicators in an estimation digital economic model of public welfare level in Ukraine in the context of the COVID-19 pandemic

Source: Developed by the authors.

\begin{tabular}{|c|c|c|c|c|c|}
\hline \multirow[t]{2}{*}{ Indicator (factor) } & \multirow{2}{*}{$\begin{array}{l}\text { Notation } \\
\text { keys }\end{array}$} & \multirow[t]{2}{*}{ Range } & \multirow{2}{*}{$\begin{array}{l}\text { Linguistic assessment } \\
\text { parameters (terms) and the } \\
\text { range of their change }\end{array}$} & \multicolumn{2}{|c|}{$\begin{array}{l}\text { Values of b and c parameters } \\
\text { of the membership function }\end{array}$} \\
\hline & & & & b & C \\
\hline \multirow{3}{*}{ Gross Domestic Product } & \multirow{3}{*}{ GDP } & \multirow{3}{*}{$\begin{array}{l}50-500 \\
\text { billion USD }\end{array}$} & $\operatorname{Low}(L), 50 \ldots 200$ & 130 & 80 \\
\hline & & & Average (A), $200 \ldots 350$ & 280 & 100 \\
\hline & & & High $(H), 350 \ldots 500$ & 420 & 120 \\
\hline \multirow{3}{*}{ Poverty Index } & \multirow{3}{*}{$\mathrm{PI}$} & \multirow{3}{*}{$0-100, \%$} & $\operatorname{Low}(\mathrm{L}), 0 \ldots 15$ & 7 & 10 \\
\hline & & & Average $(A), 15 \ldots 40$ & 25 & 15 \\
\hline & & & High (H), 40...100 & 60 & 30 \\
\hline \multirow{3}{*}{ Legatum Prosperity Index } & \multirow{3}{*}{ LPI } & \multirow{3}{*}{$0-167$} & Low (L), 100...167 & 135 & 75 \\
\hline & & & Average $(A), 50 \ldots 100$ & 70 & 55 \\
\hline & & & $\operatorname{High}(H), 0$ & 20 & 30 \\
\hline \multirow{3}{*}{ Human Development Index } & \multirow{3}{*}{$\mathrm{HDI}$} & \multirow{3}{*}{$0-1$} & $\operatorname{Low}(L), 0 \ldots 0,3$ & 0,15 & 2 \\
\hline & & & Average $(A), 0,3 \ldots 0,7$ & 0,45 & 3 \\
\hline & & & High $(H), 0,7 \ldots 1$ & 0,85 & 2 \\
\hline \multirow{3}{*}{ Living Wage } & \multirow{3}{*}{ LW } & \multirow{3}{*}{$\begin{array}{l}\text { 50...1000, } \\
\text { USD }\end{array}$} & $\operatorname{Low}(L), 50 \ldots 310$ & 20 & 10 \\
\hline & & & Average $(A), 310 \ldots 810$ & 500 & 120 \\
\hline & & & High $(H), 810 \ldots 1000$ & 900 & 150 \\
\hline \multirow{3}{*}{$\begin{array}{l}\text { Total number of COVID-19 cases } \\
\text { in Ukraine }\end{array}$} & \multirow{3}{*}{$\mathrm{CC}$} & \multirow{3}{*}{$\begin{array}{l}\text { 1-40, million } \\
\text { people }\end{array}$} & $\operatorname{Low}(\mathrm{L}), 0,5 \ldots 1$ & 0,7 & 5 \\
\hline & & & Average $(A), 1 \ldots 3$ & 2 & 10 \\
\hline & & & $\operatorname{High}(H), 3 \ldots 40$ & 20 & 30 \\
\hline \multirow{3}{*}{$\begin{array}{l}\text { Total number of deaths from } \\
\text { COVID-19 in Ukraine }\end{array}$} & \multirow{3}{*}{$C D$} & \multirow{3}{*}{$\begin{array}{l}20-500 \\
\text { thousand } \\
\text { people }\end{array}$} & $\operatorname{Low}(L), 10 \ldots 30$ & 15 & 12 \\
\hline & & & Average $(A), 30 \ldots 50$ & 40 & 30 \\
\hline & & & High $(H), 50 \ldots 500$ & 300 & 200 \\
\hline \multirow{3}{*}{$\begin{array}{l}\text { Total number of COVID-19 } \\
\text { vaccinations in Ukraine }\end{array}$} & \multirow{3}{*}{$\mathrm{CV}$} & \multirow{3}{*}{$\begin{array}{l}\text { 0-40, million } \\
\text { people }\end{array}$} & $\operatorname{Low}(\mathrm{L}), 0 \ldots 1$ & 0,7 & 5 \\
\hline & & & Average $(A), 1 \ldots 10$ & 5 & 15 \\
\hline & & & High $(H), 10 . .40$ & 25 & 20 \\
\hline \multirow{5}{*}{$\begin{array}{l}\text { Index of Public Welfare in } \\
\text { Ukraine in the COVID-19 context }\end{array}$} & \multirow{5}{*}{ IPWU } & & Very Low, $\left(I P W U_{5}\right), 0 \ldots .21$ & 10 & 12 \\
\hline & & & Low $\left(I P W U_{4}\right), 22 \ldots 41$ & 30 & 15 \\
\hline & & $0 \ldots 100$ & Average $\left(\right.$ IPWU $\left._{3}\right), 22 \ldots 61$ & 50 & 28 \\
\hline & & & Above Average $\left(I P W U_{2}\right), 62 \ldots 82$ & 70 & 20 \\
\hline & & & High $\left(I P W U_{1}\right), 83 \ldots 100$ & 90 & 17 \\
\hline
\end{tabular}



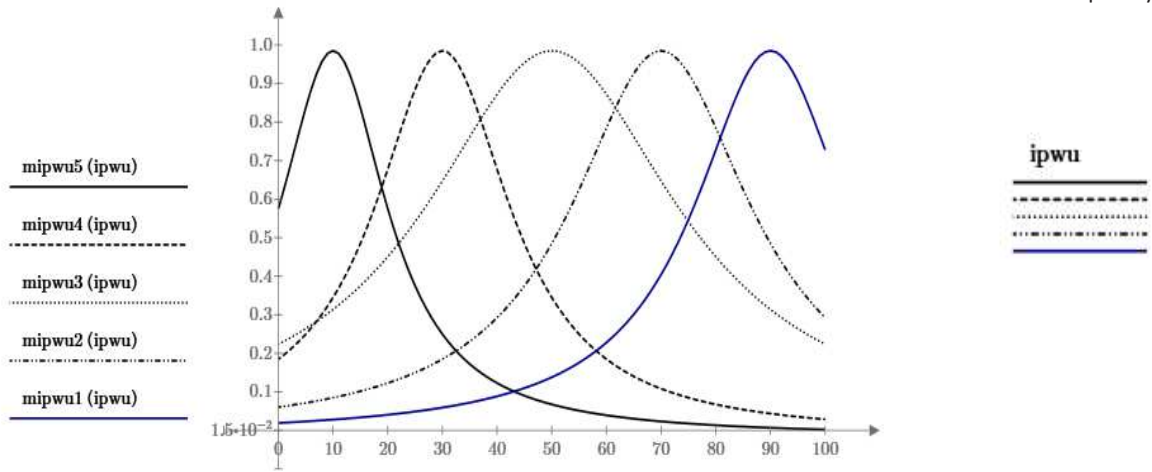

Figure 10. Membership function of the output IPWU

$I P W U=f_{i p w u}\left(\begin{array}{l}G D P, P I, L P I, H D I, \\ L W, C C, C D, C V, t\end{array}\right)$,

where $t$ is the period of determining the state (or forecasting), $t_{1}=6$ months; $t_{2}=1$ year; $t_{3}=2$ years; $t_{4}=5$ years.

The graph of the membership function of the output IPWU is shown in Figure 10.

The next step is to create a hierarchy-bound database, i.e., determining the influence of input values on the output ones. To build a database, information provided by international organizations was used (World Economic Forum, 2020). The database of IPWU value dependence on GDP, PI, LPI, $\mathrm{HDI}$, LW, CC, CD, CV, $\mathrm{t}$ is presented in Table 2.

Table 2. Database of the IPWU value

\begin{tabular}{|c|c|c|c|c|c|c|c|c|c|}
\hline GDP & PI & LPI & HDI & LW & CC & $C D$ & CV & $t$ & IPWU \\
\hline $\mathrm{H}$ & $\mathrm{L}$ & $\mathrm{H}$ & $\mathrm{H}$ & $\mathrm{H}$ & L & $\bar{L}$ & $\mathrm{H}$ & $t_{1}$ & $\mathrm{IPWU}_{1}$ \\
\hline A & L & A & $\mathrm{H}$ & $\mathrm{H}$ & L & L & A & $t_{3}$ & $\mathrm{IPWU}_{1}$ \\
\hline A & A & $\mathrm{H}$ & A & A & A & L & $\mathrm{H}$ & $t_{2}$ & IPWU \\
\hline $\mathrm{H}$ & A & A & A & $\mathrm{H}$ & L & L & $\mathrm{H}$ & $t_{4}$ & IPWU \\
\hline A & L & A & $\mathrm{H}$ & A & A & A & A & $t_{1}$ & IPWU \\
\hline $\mathrm{H}$ & A & L & A & $\mathrm{H}$ & $\mathrm{H}$ & A & $\mathrm{H}$ & $t_{2}$ & $\mathrm{IPWU}_{3}$ \\
\hline A & A & A & A & A & A & A & A & $t_{3}$ & IPWU \\
\hline L & A & A & $\mathrm{H}$ & L & L & A & L & $t_{1}$ & $\mathrm{IPWU}_{4}$ \\
\hline L & A & A & A & L & A & $\mathrm{H}$ & A & $t_{2}$ & $I P W U_{5}$ \\
\hline L & $\mathrm{H}$ & L & L & L & $\mathrm{H}$ & $\mathrm{H}$ & L & $t_{4}$ & IPWU \\
\hline
\end{tabular}

Based on the resulting database (Table 2), equations of the model will be developed, which are the input equations of the model for assessing the level of social welfare in Ukraine in the context of the COVID-19 pandemic.

$$
\begin{aligned}
& \mu^{I P W U 1}(I P W U)=\left[\mu^{H}(G D P) \cdot \mu^{L}(P I)\right] \vee \\
& \vee\left[\mu^{H}(L P I) \cdot \mu^{H}(H D I) \cdot \mu^{H}(L W)\right] \vee \\
& \vee\left[\mu^{L}(C C) \cdot \mu^{L}(C D) \cdot \mu^{H}(C V) \cdot \mu^{t_{1}}(t)\right] \vee \\
& \vee\left[\mu^{A}(G D P) \cdot \mu^{L}(P I) \cdot \mu^{A}(L P I)\right] \vee \\
& \vee\left[\mu^{H}(H D I) \cdot \mu^{H}(L W) \cdot \mu^{L}(C C)\right] \vee \\
& \vee\left[\mu^{L}(C D) \cdot \mu^{A}(C V) \cdot \mu^{t_{3}}(t)\right] \\
& \mu^{I P W U 2}(I P W U)=\left[\mu^{A}(G D P) \cdot \mu^{A}(P I)\right] \vee \\
& \vee\left[\mu^{H}(L P I) \cdot \mu^{A}(H D I) \cdot \mu^{A}(L W) \cdot \mu^{A}(C C)\right] \vee \\
& \vee\left[\mu^{L}(C D) \cdot \mu^{H}(C V) \cdot \mu^{t_{2}}(t)\right] \vee \\
& \vee\left[\mu^{H}(G D P) \cdot \mu^{A}(P I) \cdot \mu^{A}(L P I)\right] \vee \\
& \vee\left[\mu^{A}(H D I) \cdot \mu^{H}(L W) \cdot \mu^{L}(C C)\right] \vee \\
& \vee\left[\mu^{L}(C D) \cdot \mu^{H}(C V) \cdot \mu^{t_{4}}(t)\right] ; \\
& \vee \\
& \vee\left[\mu^{I P W U 3}(I P W U)=\left[\mu^{A}(G D P) \cdot \mu^{L}(P I)\right] \vee\right. \\
& \vee\left[\mu^{A}(L P I) \cdot \mu^{H}(H D I) \cdot \mu^{A}(L W)\right] \vee \\
& \vee\left[\mu^{A}(C C) \cdot \mu^{A}(C D) \cdot \mu^{A}(C V) \cdot \mu^{t_{1}}(t)\right] \vee \\
& \vee\left[\mu^{A}(C D) \cdot \mu^{H}(C V) \cdot \mu^{t_{2}}(t)\right] ; \\
& \\
& \left.\vee[P I) \cdot \mu^{L}(L P I)\right] \vee \\
&
\end{aligned}
$$




$$
\begin{aligned}
& \mu^{I P W U 4}(I P W U)=\left[\mu^{A}(G D P) \cdot \mu^{A}(P I)\right] \vee \\
& \vee\left[\mu^{A}(L P I) \cdot \mu^{A}(H D I) \cdot \mu^{A}(L W)\right] \vee \\
& \vee\left[\mu^{A}(C C) \cdot \mu^{A}(C D) \cdot \mu^{A}(C V) \cdot \mu^{t_{3}}(t)\right] \vee \\
& \vee\left[\mu^{L}(G D P) \cdot \mu^{A}(P I) \cdot \mu^{A}(L P I)\right] \vee \\
& \vee\left[\mu^{H}(H D I) \cdot \mu^{L}(L W) \cdot \mu^{L}(C C)\right] \vee \\
& \vee\left[\mu^{A}(C D) \cdot \mu^{L}(C V) \cdot \mu^{t_{1}}(t)\right] ; \\
& \mu^{I P W U 5}(I P W U)=\left[\mu^{L}(G D P) \cdot \mu^{A}(P I)\right] \vee \\
& \vee\left[\mu^{A}(L P I) \cdot \mu^{A}(H D I) \cdot \mu^{L}(L W)\right] \vee \\
& \vee\left[\mu^{A}(C C) \cdot \mu^{H}(C D) \cdot \mu^{A}(C V) \cdot \mu^{t_{2}}(t)\right] \vee \\
& \vee\left[\mu^{L}(G D P) \cdot \mu^{H}(P I) \cdot \mu^{L}(L P I)\right] \vee \\
& \vee\left[\mu^{L}(H D I) \cdot \mu^{L}(L W) \cdot \mu^{H}(C C)\right] \vee \\
& \vee\left[\mu^{H}(C D) \cdot \mu^{L}(C V) \cdot \mu^{t_{4}}(t)\right] .
\end{aligned}
$$

To obtain simulation results, the defasification process proposed by Rotshtein (1999) and Rotshtein and Shtovba (2009) was carried out the procedure for obtaining the result is described in detail in Rotshtein (1999).

An experiment was performed using the aforementioned technique in the mathematical kit Matlab 6.1 (Pratar, 1999). The result of assessing and until 2025 is shown in Figure 11.
After analyzing the results, the following forecast was achieved: the level of public welfare in Ukraine in the context of the COVID-19 pandemic will be low until 2025. Generally, this illustrates a negative development trend of Ukraine's national economy.

These conditions create a need to determine which variable most affects the level of public welfare in Ukraine. Figures 12 and 13 present the efficiency of the IPWU output from paired values (GDP, CC) and (LW, CC), made in the Matlab mathematical complex using the Image Toolbox (Pratar, 1999).

Figures 12 and 13 reveal the impact of those variables on the level of public welfare. Importantly, three indicators drastically decrease the level of public welfare in the context of the COVID-19 pandemic, in particular, LW (living wage), GDP (gross domestic product), and CC (total number of COVID-19 cases in Ukraine).

\section{DISCUSSION}

So far certain macro-social indicators associated with societal well-being were used to research the level of public welfare. This stems from the utmost need of analytically examining factors and manifestations of feelings of individuals, which, in turn, form the society. Secondly, all statistical data and development must have been taken into account. However, these two aspects did not prevent the assessment of the basic processes of social dynamics,

Source: Developed by the authors.

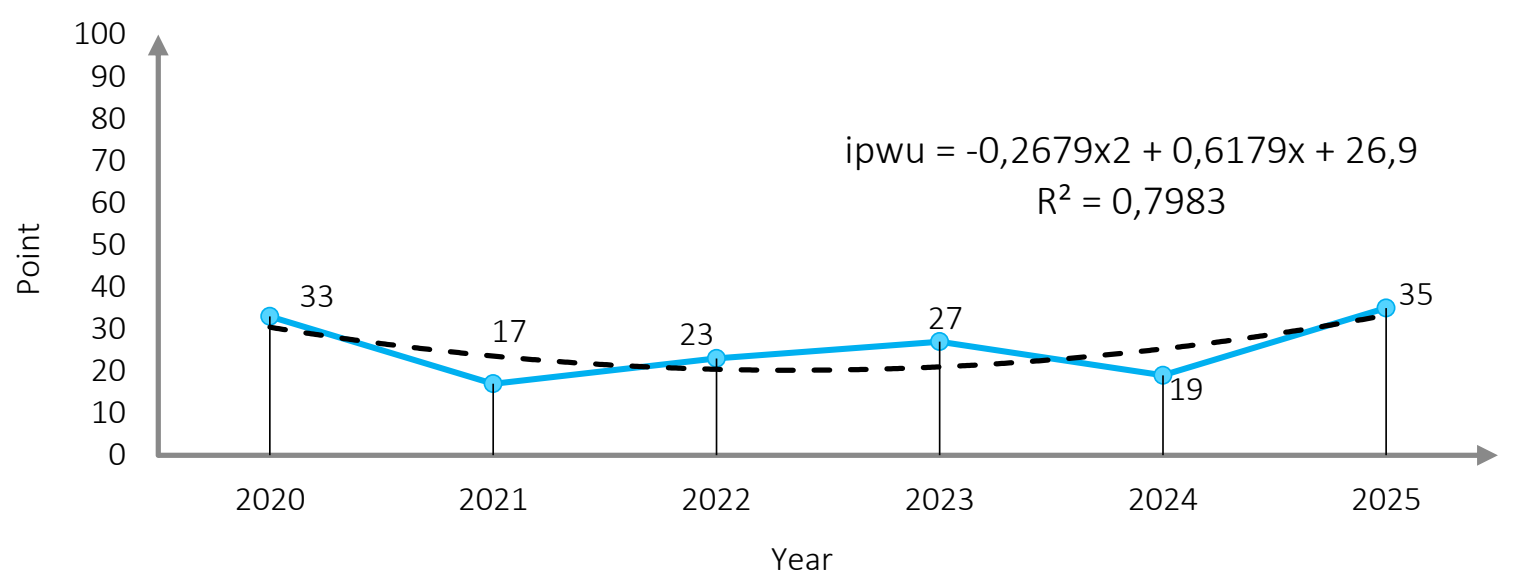

Figure 11. The results of the assessment and forecasting the level of public welfare in Ukraine in the context of the COVID-19 pandemic 
Source: Developed by the authors.

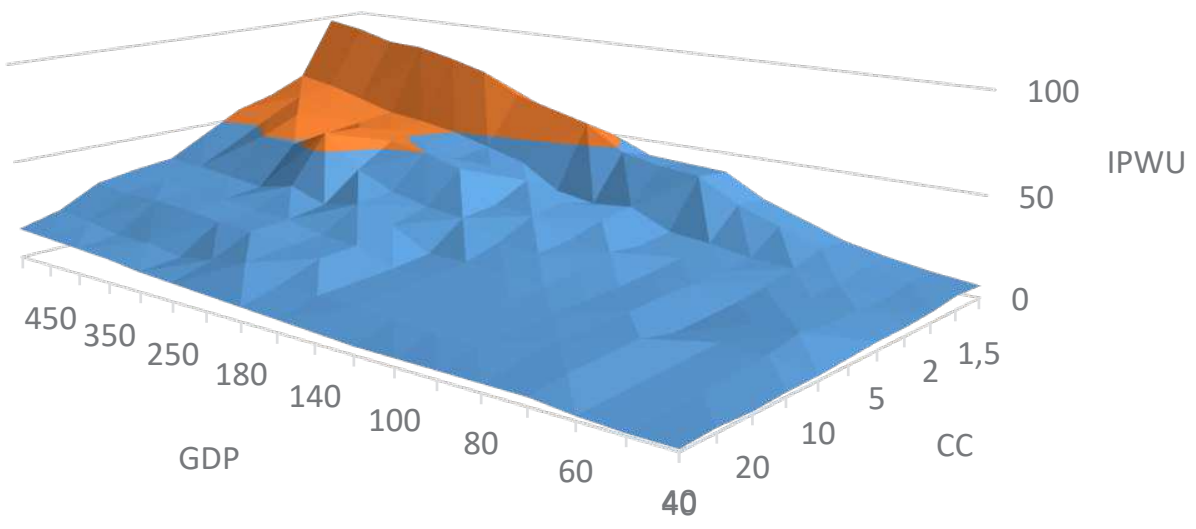

Figure 12. Graph representing the two-dimensional correlation of IPWU (GDP, CC)

Source: Developed by the authors.

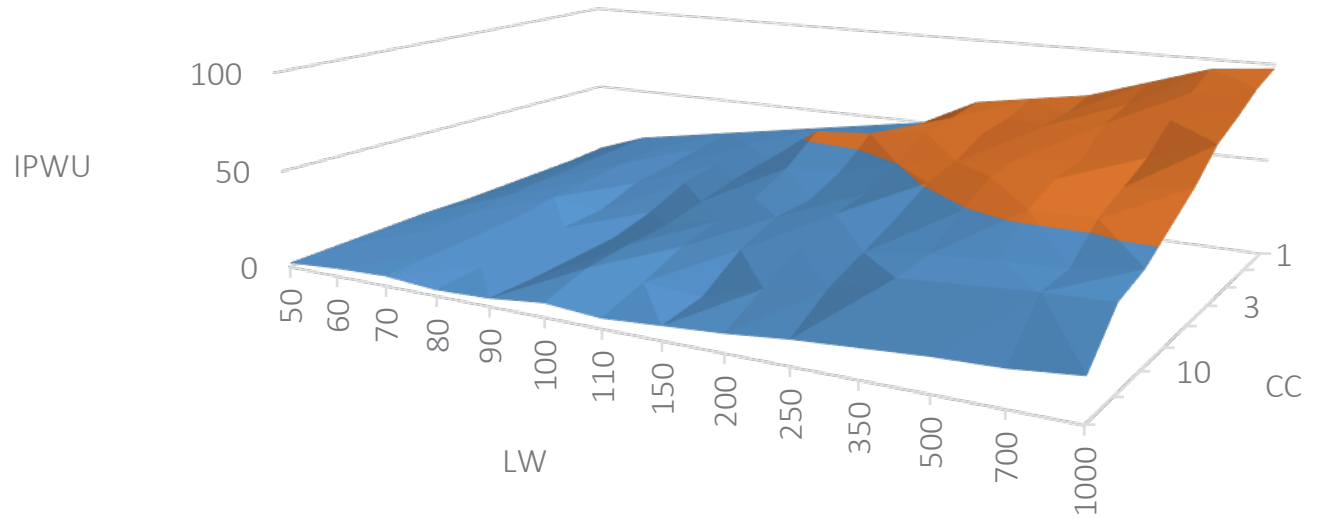

Figure 13. Graph representing the two-dimensional correlation of IPWU (LW, CC)

particularly because of complex and unclear relationships between parameters. For instance, the majority of the previously analyzed values exhibit correlation, which often has unobvious causation. In this case, obtaining a mathematical solution became possible due to the use of methods of the digital economy - artificial intelligence methods the methods of fuzzy sets theory.

The problem of assessing the measurement and provision of public welfare, especially in the context of pandemics, is always highly politicized, as there are different views on the nature of newly-emerged problems. According to the American scholar DiNitto (2003), social welfare policies are always debated: how to properly define "benefits" and "value," how to identify the needs and whose needs to prioritize, and how rational the government can be in choosing appropriate intervention mechanisms. In other words, subjective factors have a far-reaching influence in shaping the societal understanding of public welfare.

One of the most effective approaches to assessing public welfare from the standpoint of sustainable development theories is presented in the study by Koziuk et al., 2020. This study shows the inverse dependence of the degree of heterogeneity of public welfare on the quality of the environment. It is proved that the quality of governance can weaken the inverse relationship between ethnic fractionalization and the ecological situation in the country. In the welfare states, the neutralization factor of ethnic fractionalization by the quality of governance institutions is traced, which testifies to the existence of an institutional transmission buffer mechanism in the relationship between the structure of society and the offer of environmental goods (Koziuk et al., 2020). However, this approach does not reveal other features and compo- 
nents of public welfare, such as the level of poverty, the level of economic development, the level of human development, etc. The developed scientific approach only reveals the ecological aspect in the process of forming the level of public welfare.

Modern interpretations of the concept of "public welfare" vary. On the one hand, some scientists associate it with material circumstances necessary for the renewal of human energy. They measure this well-being using macroeconomic indicators such as the size of GDP per capita, poverty level, living wage level, etc. On the other hand, other scientists believe that public welfare involves not only income and social contract but also societal goods. It can be measured through a chain of objective indicators, such as the legatum prosperity index, healthcare, and mortality rates in various socio-economic groups. Normative indicators, such as the living wage and the average salary (pension), are used to measure public welfare in Ukraine. These characteristics do not fully reflect market conditions of economic development and the structure of household income. Neither do they take into account indirect and subjective assessments, which give a more comprehensive description of public welfare. The rates of different diseases, the state of pandemics, and methods of tackling those pandemics have become integral indicators in modern society. In late 2019, the world faced a new issue, the COVID-19 pandemic, which fundamentally changed the assessment of the level of social welfare of the world population. To realistically assess the state of public welfare, one must consider the disease and vaccination rates against COVID-19.

\section{CONCLUSION}

The main idea of this study was to assess the level of public welfare in Ukraine in the COVID-19 pandemic and economy digitalization. To do this, the factors influencing the overall indicator of public welfare were established, bearing in mind the factors of the COVID-19 pandemic. A digital economic model for assessing the level of public welfare has been developed. The relationships were established between the indicator of public welfare and the value of GDP, the subsistence level and the total number of cases of COVID-19 in Ukraine. As a result, an approach to assessing the level of social welfare in Ukraine during the COVID-19 pandemic was proposed and an assessment of public welfare until 2025 was given.

This study offers an entirely new approach to assessing and forecasting the level of public welfare in the context of the COVID-19 pandemic. It involves using variables provided by international organizations that reflect the economic and societal states of the country, namely: gross domestic product (GDP); poverty index (PI); Legatum prosperity index (LPI); human development index (HDI); living wage (LW); the number of COVID-19 cases in Ukraine (CC); the number of deaths from COVID-19 in Ukraine (CD); the total number of COVID-19 vaccinations in Ukraine (CV).

Due to the use of methods of digital economy - methods of fuzzy sets theory, it was determined that the level of public welfare in Ukraine in the context of the COVID-19 pandemic is at a very low level, much lower than world standards. Forecasting the value of this indicator until 2025, it is established that this indicator will remain low.

\section{AUTHOR CONTRIBUTIONS}

Conceptualization: Serhii Kozlovskyi, Viktoriia Baidala.

Data curation: Viktoriia Myronchuk, Tetiana Kulinich.

Formal analysis: Viktoriia Baidala, Viktoriia Myronchuk.

Funding acquisition: Tetiana Kulinich, Viktoriia Myronchuk.

Investigation: Serhii Kozlovskyi.

Methodology: Serhii Kozlovskyi, Iaroslav Petrunenko. 
Project administration: Serhii Kozlovskyi.

Resources: Iaroslav Petrunenko, Viktoriia Baidala.

Software: Tetiana Kulinich, Iaroslav Petrunenko.

Supervision: Serhii Kozlovskyi.

Validation: Serhii Kozlovskyi, Viktoriia Baidala.

Visualization: Viktoriia Myronchuk, Tetiana Kulinich.

Writing - original draft: Serhii Kozlovskyi, Iaroslav Petrunenko.

Writing - review \& editing: Serhii Kozlovskyi, Viktoriia Baidala.

\section{REFERENCES}

1. Adam Smith. (1776). An Inquiry into the Nature and Causes of the Wealth of Nations. Retrieved from https://www.libertyfund. org/books/an-inquiry-into-thenature-and-causes-of-the-wealthof-nations-Vol-1

2. Arrow, K. J. (1951). Social Choice and Individual Values. New Haven. New York. Retrieved from https:// www.worldcat.org/title/socialchoice-and-individual-values/ oclc/892549124

3. Babenko, V., Nehrey, M., Gaponova, E., Ryzhikova, N., \& Zaporozhets, E. (2019). Life Expectancy of Population of the Country: The Role of Health Services Effectiveness. Research in World Economy, 10, 86-91. Retrieved from http:// www.sciedu.ca/journal/index.php/ rwe/article/view/16906

4. Banerjee, A., Duflo, E., \& Kremer, M. (2016). The Influence of Randomized Controlled Trials on Development Economics Research and on Development Policy. The State of Economics, The State of the World, 11, 1-76. Retrieved from http://economics.mit.edu/ files/16485

5. Bell, D. (1976). The Cultural Contradictions of Capitalism. NewYork. Basic Books. Retrieved from http://voidnetwork.gr/wp-content/ uploads/2016/08/The-CulturalContradictions-of-Capitalism-byDaniel-Bell.-Book.pdf

6. Bergson, H. (1911). Creative Evolution (Authorized translation by Arthur Mitchell). Henry Holt and Company. Retrieved from https://www.gutenberg.org/ files/26163/26163-h/26163-h.htm

7. Byrdyn, A. (2008). Goals and criteria for socio-economic development of the region. State building, 1, 1-10. Retrieved from http://irbis-nbuv.gov.ua/cgi-bin/ irbis_nbuv/cgiirbis_64.exe?C21 $\mathrm{COM}=2 \& \mathrm{I} 21 \mathrm{DBN}=\mathrm{UJRN} \& \mathrm{P} 2$ $1 \mathrm{DBN}=$ UJRN\&IMAGE_FILE_ DOWNLOAD $=1 \&$ Image_file name $=$ PDF/DeBu_2008_1_37.pdf

8. Campbell, A., Philip, E., \& Willard, 1. (1976). The Quality of American Life: Perceptions, evaluations, and satisfactions. New York. Russell Sage. Retrieved from https://www. russellsage.org/sites/default/files/ QualityAmLife.pdf

9. Daqar, M., Constantinovits, M., Arqawi, S., \& Daragmeh, A. (2021). The role of Fintech in predicting the spread of COVID-19. Banks and Bank Systems, 16(1), 1-16. https://doi.org/10.21511/ bbs.16(1).2021.01

10. Derbentsev, V., Matviychuk, A., \& Soloviev, V. (2020). Forecasting of Cryptocurrency Prices Using Machine Learning. Advanced Studies of Financial Technologies and Cryptocurrency Markets, 30, 211231. https://doi.org/10.1007/978981-15-4498-9_12

11. Dinitto, D. M., \& Johnson, D. H. (2003). Social Welfare: Politics and Public Policy. Boston. Pearson Education. Retrieved from https://www.pearson.com/us/ higher-education/program/ Di-Nitto-Social-Welfare-Politicsand-Public-Policy-with-Enhanced-Pearson-e-Text-AccessCard-Package-8th-Edition/ PGM285699.html

12. Erikson, R. (1993). Description of Inequality: The Swedish Approach to Welfare Research. The Quality of Life. Oxford. Retrieved from https://oxford.universi- typressscholarship.com/view/1 0.1093/0198287976.001.0001/ acprof-9780198287971-chapter7 ?print $=$ pdf

13. Human Development Report. (2020). The Next Frontier: Human Development and the Anthropocene. United Nations Development Programme. Retrieved from http://hdr.undp.org/en/content/ human-development-report-2004

14. Human Development Index. (2020). Human Development Reports of United Nations Development Programme. Retrieved from http://hdr.undp.org/ en/indicators/137506

15. Ilyash, O., Hrynkevych, S., Illich, 1., Kozlovskyi, S., \& Buhaychuk, N. (2020). Economic Assessment of the Relationship Between Housing and Communal Infrastructure Development Factors and Population Quality of Life in Ukraine. Montenegrin Journal of Economics, 16(3), 93-108. Retrieved from http://www.mnje.com/sites/mnje. com/files/093-108_-_olha_ilyash_ kozlovski_et_al._-_ukr._-_rrr.pdf

16. Koziuk, V., Dluhopolskyi, O., \& Petruk, V. (2019). Globalization, innovation and fragility of optimal fiscal zones: secessions risks of Belgium, lessons for Ukraine. Ideology and Politics Journal, 1(12), 60-90. Retrieved from https:// www.ideopol.org/wp-content/ uploads/2019/11/_ENG.\%20 1.9.\%20Koziuk\%20Dlugopolsky\%20Petruk\%20FIN.pdf

17. Koziuk, V., Hayda, Y., Dluhopolskyi, O., \& Kozlovskyi, S. (2020). Ecological performance: ethnic fragmentation versus governance quality and sustainable development. Problemy ekorozwoju 
- Problems of sustainable development, 15(1), 53-64. Retrieved from https://ekorozwoj.pollub.pl/no29/h. pdf

18. Kozlovskyi, S., Mazur, H., Vdovenko, N., Shepel, T., \& Kozlovskyi, V. (2018). Modeling and forecasting the level of state stimulation of agricultural production in Ukraine based on the theory of fuzzy logic. Montenegrin Journal of Economics, 14(3), 37-53. https://doi. org/10.14254/1800-5845/2018.143.3

19. Kozlovskyi, S., Nikolenko, I., Peresada, O., Pokhyliuk, O., Yatchuk, O., Bolgarova, N., \& Kulhanik, O. (2020). Estimation level of public welfare on the basis of methods of intellectual analysis. Global Journal of Environmental Science and Management, 6(3), 355-372. http://dx.doi. org/10.22034/gjesm.2020.03.06

20. Kozlovskyi, S., Bilenko, D., Dluhopolskyi, O., Vitvitskyi, S., Bondarenko, O., \& Korniichuk, O. (2021). Determinants of COVID-19 death rate in Europe: empirical analysis. Problemy Ekorozwoju, Problems of Sustainable Development, 16(1), 17-28. Retrieved from https:// ekorozwoj.pollub.pl/index.php/ number-1612021/determinantsof-covid-19-death-rate-in-europeempirical-analysis/

21. Law of Ukraine. (2000). On State Social Standards and State Social Guarantees, 48. Retrieved from https://zakon.rada.gov.ua/laws/ show/2017-14\#Text

22. Legatum Institute. (2021). Retrieved from https:/li.com/

23. List, S., \& Goodin, R. (2001). Epistemic democracy: generalizing the Condorcet Jury Theorem. Journal of Political Philosophy, 9(3), 277-306. https://doi.org/10.1111/14679760.00128

24. Libanova, E. (2020). Poverty of the population of Ukraine: methodology, methods and practice of analysis. Uman. Sochinsky. Retrieved from https://idss.org.ua/arhiv/Бідність населення України методологія, методика та практика аналізу.pdf

25. Matviychuk, A., Strelchenko, I., Vashchaiev, S., \& Velykoivanenko, H. (2019). Simulation of the Crisis Contagion Process Between
Countries with Different Levels of Socio-Economic Development. Proceedings of the 15th International Conference on ICT in Education, Research and Industrial Applications. Integration, Harmonization and Knowledge Transfer. Retrieved from http://ceur-ws.org/Vol-2393/ paper_423.pdf

26. Matviychuk, A., Lukianenko, O., \& Miroshnychenko, I. (2019). Neurofuzzy model of country's investment potential assessment. Fuzzy Economic Review, 24(2). Retrieved from http://www.sigef.net/2014-09-2607-16-23/summaries-and-abstracts/ item/653-neuro-fuzzy-model-ofcountry-s-investment-potentialassessment

27. Nikolenko, L., Jurakovskiy, E., Ivanyuta, N., Andronik, O., \& Sharkovska, S. (2018). Investment policy of governance of economic security of agrarian sector of Ukraine on the basis of the theory of fuzzy logics. Montenegrin Journal of Economics, 14(4), 125-140. Retrieved from http://www.mnje.com/sites/mnje. com/files/125-_140_-_nikolenko_ et_al.pdf

28. Oliinyk, V., \& Kozmenko, S. (2019). Forecasting and management of gross domestic product. Journal of International Studies, 12(4), 214-228. Retrieved from https://www.jois.eu/ files/14_799_Oliinyk_Kozmenko. pdf

29. Official Site of Minfin. (2020). Living wage in Ukraine 2020. Retrieved from https://index.minfin.com.ua/ labour/wagemin

30. Panoshichen, Y., \& Kozachko, O. (2010). Fuzzy model for assessing the creditworthiness of individualsborrowers of commercial banks. Visnyk HNU, 1(T2), 161-168. (In Ukrainian). Retrieved from http://dspace.tneu.edu.ua/bitstream/316497/17218/1/stattia $\% 20$ (1).pdf

31. Pareto, V. (1935). The mind and society [Trattato di sociologia generale]. New York. Harcourt, Brace. Retrieved from https://openlibrary.org/books/OL6319598M/ The_mind_and_society

32. Pigou, A. (1932). The economics of welfare. London. Macmillan. Re- trieved from http://files.libertyfund. org/files/1410/0316_Bk.pdf

33. Petrova, I., Balyka, O., \& Kachan, H. (2020). Digital economy and digital employment appearence. Social and labour relations: theory and practice, 10(2), 10-20. http://dx.doi. org/10.21511/slrtp.10(2).2020.02

34. Potapov, I. (2011). Social welfare: the essence of the concept in the context of modern theoretical approaches. Theoretical and applied issues of state formation, 8, 430-447.

35. Pratar, R. (1999). Getting started with Matlab 5. A quick introduction for scientists and engineers. Oxford University Press. Retrieved from https://books. google.com.ua/books/about/Getting_Started_with_MATLAB_5. html?id=CoKPQgAACAAJ\&redir_ esc $=\mathrm{y}$

36. Ptoukha institute for demography and social studies of the National Academy of Sciences of Ukraine. (2020). Influencing the coronavirus crisis on the daily life: the first legacies for Ukraine. Retrieved from https://idss.org.ua/arhiv/poverty_ forecast.pdf

37. Rotshtein, A. (1999). Intellectual identification technologies: fuzzy logic, genetic algorithms, neural networks. Vinnytsia: Universum.

38. Rotshtein, A., \& Shtovba, S. (2009). Modeling of the Human Operator Reliability with the Aid of the Sugeno Fuzzy Knowledge Base. Automation and Remote Control, 70, 163-169. Retrieved from http://www. serhiy-shtovba.narod.ru/doc/Rotshtein_Shtovba_ARC_2009_1.pdf

39. Schumpeter, J. A. (1908). Das Wesen und der Hauptinhalt der theoretischen Nationalökonomie. Germany: Leipzig, Duncker \& Humblot. Retrieved from https:// www.worldcat.org/title/wesen-undder-hauptinhalt-der-theoretischennationalokonomie/oclc/5455469

40. The Legatum Prosperity Index. (2020). Official site of Legatum Institute. Retrieved from https://www. prosperity.com/rankings

41. The World Bank. (2020). Gross domestic product of Ukraine at current prices. Retrieved from https://data. 
worldbank.org/indicator/NY.GDP.

MKTP.CD? end $=2019$ \&locations $=\mathrm{U}$ A\&start $=1990$

42. The United Nations. (2021). Working arrangements for the 2021 session of the Economic and Social Council. Retrieved from https://www.un.org/ ga/search/view_doc.asp?symbol=E/ RES/2021/1

43. The International Monetary Fund. (2021). Policy Support and Vaccines Expected to Lift Activity. Retrieved from https://www. imf.org/en/Publications/WEO/
Issues/2021/01/26/2021-worldeconomic-outlook-update

44. Tsymbaliuk, S., Wyrwa, D., \& Shkoda, T. (2019). Remuneration policy in terms of decent work at a regional level. Problems and Perspectives in Management, 17(4), 80-92. https://doi.org/10.21511/ ppm.17(4).2019.07

45. United Nations Development Programme. (2020). Retrieved from https://www.undp.org/

46. Weizsacker, E. U., \& Wijkman, A. (2018). Come on! Capitalism, Short- termism, Population and Destruction of the Planet - A Report to the Club of Rome. Springer Science+Business Medis LLC. New York. Retrieved from http://filipmalinowski.net/ Club_Of_Rome-report-2018_ComeOn.pdf

47. Worldometer (2021). Coronavirus in Ukraine. Retrieved from https:// www.worldometers.info /coronavirus/ country/ukraine/

48. World Economic Forum. (2020). Retrieved from https://www. weforum.org/ 